Against the Law 



\title{
Against the Law
}

Labor Protests in China's Rustbelt and Sunbelt

\author{
CHING KWAN LEE
}

\section{甲}

University of California Press

BERKELEY LOS ANGELES LONDON 
University of California Press, one of the most distinguished university presses in the United States, enriches lives around the world by advancing scholarship in the humanities, social sciences, and natural sciences. Its activities are supported by the UC Press Foundation and by philanthropic contributions from individuals and institutions. For more information, visit www.ucpress.edu.

University of California Press

Berkeley and Los Angeles, California

University of California Press, Ltd.

London, England

(C) 2007 by The Regents of the University of California

Library of Congress Cataloging-in-Publication Data

Lee, Ching Kwan.

Against the law : labor protests in China's rustbelt and sunbelt /

Ching Kwan Lee.

p. $\mathrm{cm}$.

Includes bibliographical references and index.

ISBN-13: 978-0-520-25097-O (pbk. : alk. paper)

ISBN-10: 0-520-25097-4 (pbk. : alk. paper)

ISBN-13: 978-0-520-23222-8 (cloth : alk. paper)

ISBN-10: 0-520-23222-4 (cloth : alk. paper)

1. Working class-China-Guangdong Sheng. 2. Working class-

China-Liaoning Sheng. 3. Demonstrations-China-Guangdong

Sheng. 4. Demonstrations-China-Liaoning Sheng. I. Title.

HD8739.G828L44 2007

$331.0951^{\prime} 27-\mathrm{dc} 22$

2006021879

Manufactured in the United States of America

$\begin{array}{lllllllll}15 & 14 & 13 & 12 & 11 & 10 & 09 & 08 & 07\end{array}$

$\begin{array}{llllllllll}10 & 9 & 8 & 7 & 6 & 5 & 4 & 3 & 2 & 1\end{array}$

This book is printed on New Leaf EcoBook 50, a 100\% recycled fiber of which $50 \%$ is de-inked post-consumer waste, processed chlorine-free. EcoBook 50 is acid-free and meets the minimum requirements of ANSI/ASTM D5634-OI (Permanence of Paper). 
for John 
